\title{
Pancreatic Delta Cell Neuroendocrine
} Tumor

National Cancer Institute

\section{Source}

National Cancer Institute. Pancreatic Delta Cell Neuroendocrine Tumor. NCI Thesaurus.

Code C28396.

A usually malignant neuroendocrine tumor arising from the delta cells of the pancreas. It may be associated with inappropriate secretion of somatostatin and an associated clinical syndrome, or it may be hormonally inactive (non-functioning). 